\title{
Obituary
}

\section{Selman Abraham Waksman}

IN Woods Hole, Massachusetts, on August 16, 1973, the eminent Nobel laureate microbiologist, Selman A. Waksman, died suddenly of a cerebral haemorrhage. There, three days later, he was buried far from his native Russia but close to one of the laboratories he had helped to develop.

Selman Abraham Waksman was born on July 22,1888 , in the town of Priluka near Kiev in the Ukraine. Finding it difficult, as a Jew, to enter the University of Odessa, he left for the United States in 1910. The next year Waksman entered Rutgers College (New Brunswick, New Jersey) on a State scholarship. $\mathrm{He}$ received a Bachelor of Science in Agriculture in 1915 and was elected to Phi Beta Kappa, the first of the many academic honours his incredible intellectual industry would yield. The next year, at the same institution, Waksman received a Master of Science degree for work done under the supervision of $\mathrm{Dr}$ Jacob G. Lipman. In 1918 he received a $\mathrm{PhD}$ in biochemistry from the University of California in Berkeley. Except for part-time appointments at Cutter Laboratories in California and at Takamine Laboratories in New Jersey, Dr Waksman's whole career developed at Rutgers University where he was first appointed in 1918, and promoted to Professor in 1930. In 1940 he was named head of the Department of Microbiology of the College of Agriculture, and in 1949 he became Director and founder of the Institute of Microbiology of Rutgers University. He retired in 1958 but continued for many years to direct a limited amount of research.

Dr Waksman was a prolific writer. During his life he and his collaborators published more than 500 papers and twenty-eight books. This output ranged from booklets giving practical advice on the use of enzymes for such purposes as jelly-making, soil fertilisation, and mushroom growing, to erudite historical studies. Between these two extremes stands a mass of research communications centring around soil microbiology.

While still a student at Rutgers, Dr Waksman became interested in the ecology and the taxonomy of actinomycetes. At first, he thought of these organisms merely as decomposers of organic matter playing a key role in the building of humus and the modelling of the soil. However, in 1923, he and Robert L. Starkey wrote in Soil Science: "Certain actinomycetes produce substances toxic to bacteria, as shown by
Greig-Smith (in 1917) and as often observed in our work, when around an actinomyces colony upon a plate, a zone is found free from fungus and bacterial growth.".

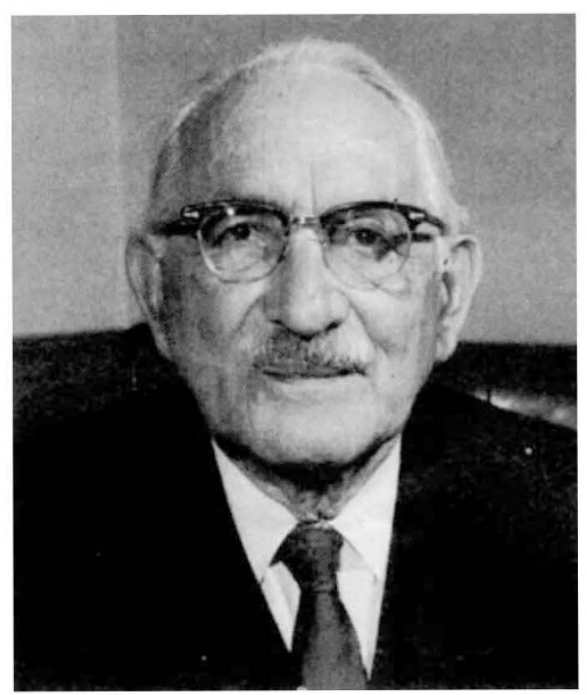

In 1937, in collaboration with Jackson W. Foster and Imri J. Hutchings, he published in the same journal a series of papers on associative and antagonistic effects of microorganisms. Following the spectacular success of his former student, René J. Dubos, who discovered tyrothricin in 1939, as well as the revival of Alexander Fleming's penicillin by Ernst B. Chain, Howard Florey and associates in 1940, Dr Waksman concentrated on the study of antibiotics. A total of twenty-two antibiotics, mainly from actinomycetes, were isolated in his laboratory, four of which have been useful enough to be produced commercially for medical use. These are actinomycin, an antitumour agent, streptomycin and neomycin, active against bacteria and mycobacteria, and candicidin, an antifungal agent. Of these, streptomycin, isolated in 1944, is the most widely employed and its use revolutionised the treatment of tuberculosis and closed many a sanatorium. For the discovery of this compound, Dr Waksman was awarded the Nobel Prize in Physiology and Medicine in 1952

Before becoming involved in the study of antibiotics, Dr Waksman concentrated on the role of microbes in the soil and in the building of humus. $\mathrm{He}$ was in turn an expert on microbial enzymes, autotrophic bacteria, especially sulphur bacteria, the formation and the use of peat, marine microbiology, the production of organic acids by fungi, the role of thermophilic organisms in composting, the taxonomy of actinomycetes, the role of heavy metals in the nutrition of fungi and the history of microbiology. In this last field, his major contributions were biographies of Haffkine, Winogradsky and Lipman.

Dr Waksman organised the division of Marine Bacteriology at Woods Hole Oceanographic Institution in 1931 and for over a decade he contributed to our knowledge of the ecology of marine microbes. In the sea, as in the soil, he was concerned with the role of microorganisms in the decomposition of organic matter. $\mathrm{He}$ recognised that microbial activity decreased with an increase in depth. He considered fungi and actinomycetes to be soil organisms which may be only casually carried to the sea from their natural habitat on land. Upon his retirement from active research at Woods Hole Oceanographic Institution in 1942, he was elected a trustee and he served in this capacity until his death.

The bulk of the royalties received from the manufacturers of streptomycin and neomycin was used to establish an Institute of Microbiology which opened its doors in 1954. The original plan of Dr Waksman was to explore six major fields of research: general microbiology, microbial physiology, antibiotics, vitamins and enzymes, microbial ecology and applied microbiology. As the Institute developed, certain fields such as the study of vitamins were neglected while others were added. Among these were immunochemistry under the leadership of Michael Heidelberger, as well as other fields such as genetics and virology.

Dr Waksman was a link between microbiologists of the United States and of the Soviet Union. He wrote numerous articles on Russian scientists and their work and visited the Soviet Union several times.

Dr Waksman was of Jewish stock, and although not a religious man he was a keen scholar of Jewish history and institutions. He visited Israel on several occasions and played a key role in the creation of the Institute of General and Industrial Microbiology of the Technion of Haifa.

A short, stocky man with a perennially busy air, Dr Waksman loved to recount stories about his life and career. They were always pertinent to the discussion or lecture of the moment, and usually provided an historical or scientific insight for his listener. He was a loyal supporter of all those who had gained his confidence and who now mourn a departed friend.

Dr Waksman is survived by his widow, Deborah B. (Mitnik) Waksman, and his son Dr Byron H. Waksman, a distinguished immunologist who is Professor of Microbiology at the Medical School of Yale University. 